doi: 10.15503.onis2021.170.177

\title{
Symbolika w filmie Nosferatu wampir Wernera Herzoga
}

\author{
Justyna Braszka \\ Wydział Filologiczny \\ Uniwersytet Łódzki \\ ul. Prez. Gabriela Narutowicza 68, 90-136 Łódź \\ E-mail: j.braszkao@gmail.com \\ ORCID: https://orcid.org/0000-0001-9800-6600
}

\begin{abstract}
Abstrakt
Cel. Celem artykułu jest przedstawienie symboliki ukrytej w filmie Nosferatu wampir w reżyserii Wernera Herzoga, zaprezentowanej na tle filmowego wampiryzmu i twórczości reżysera. Artykuł przedstawia zarys i genezę kina wampirycznego, spuściznę ekspresjonistycznej kinematografii niemieckiej i ponowne podejście Herzoga do wznowienia myśli neoromantycznej. $W$ artykule zaprezentowano także wpływ folkloru i motyw potęgi natury, który miał wpływ na reżyserię Wernera Herzoga. Wymienione wyżej tematy przeplatają się z celem głównym artykułu, czyli interpretacją filmu Nosferatu wampir.

Omówienie koncepcji. Artykuł oparty jest na teoretycznej wiedzy z zakresu kultury, zwłaszcza ze sztuki filmowej. Przyjęta koncepcja łączy w sobie opis nierozerwalnej zależności między reżyserią a wybraną przez twórcę inspiracją którą należy z kolei interpretować jako część właściwych składowych. W przypadku filmu Nosferatu wampir trzeba sięgnąć do motywów pojawiających się w gatunku filmowym jaki jest horror, a przede wszystkim w nurcie tzw. kina wampirycznego. Aspekty filmowe poszerzone o wizję Wernera Herzoga zostały uzupełnione o pozostałe motywy, m. in.: folklor.

Wnioski. Artykuł przedstawia gamę informacji na temat symboliki wykorzystywanej przez Wernera Herzoga. Omówienie Nosferatu wampir to przy tym kwestia ujęcia koncepcji metafizycznych, folklorystycznych i społecznych.

Wartość poznawcza. W artykule zaprezentowano kompleksową analizę filmu Nosferatu wampir uzupełnioną o wiedzę z zakresu sztuki filmowej, głównie kinematografii niemieckiej od okresu nurtu ekspresjonistycznego po zmiany w kinie niemieckim doby Herzoga.

Słowa kluczowe: wampir, wampiryzm, oniryzm, ludzkość, folklor, kino, film, Werner Herzog, Isabelle Adjani, Klaus Kinski, Bruno Ganz, ekspresjonizm niemiecki, neoromantyzm niemiecki, kinematografia niemiecka, Friedrich Wilhelm Murnau, Dracula, Bram Stoker
\end{abstract}

\section{Symbolism in Werner Herzog's film Nosferatu the Vampyre}




\begin{abstract}
Aim. The aim of the article is to present the symbolism hidden in the film Nosferatu the Vampyre, directed by Werner Herzog, presented against the backdrop of cinematic vampirism and the director's other works. The article presents the outline and genesis of vampire cinema, the legacy of German expressionist cinematography and Herzog's re-approach to the resumption of neo-romantic thought. The article also presents the influence of folklore and the theme of the power of nature, which influenced the work of Werner Herzog. The above-mentioned topics are intertwined with the main aim of the article, i.e. the interpretation of the film Nosferatu the Vampyre.

The concept. The article is based on theoretical knowledge in the field of culture, especially that of cinematic art. The concept adopted combines a description of the inextricable relationship between directing and the inspiration chosen by the artist, which in turn should be interpreted as part of the proper components. In the case of the film Nosferatu the Vampyre, it is necessary to refer to themes appearing in the horror film genre, and above all in the so-called vampire cinema. The cinematic aspects, extended by Werner Herzog's vision, were supplemented by other motifs, including folklore.

Conclusions. This article presents a range of information about the symbolism used by Werner Herzog. Discussion of Nosferatu the Vampyre is at the same time a matter of embracing metaphysical, folkloric and social concepts.

Cognitive value. The article presents a comprehensive analysis of the film Nosferatu the Vampyre supplemented by knowledge of cinematic art, mainly German cinematography from the expressionist period up to changes in German cinema in the Herzog era.

Key words: vampire, vampirism, onirism, humanity, folklore, cinema, film, Werner Herzog, Isabelle Adjani, Klaus Kinski, Bruno Ganz, German expressionism, German neo-romanticism, German cinematography, Friedrich Wilhelm Murnau, Dracula, Bram Stoker.

\section{Geneza}

Wraz z debiutanckim momentem pojawienia się pierwszego horroru, czyli francuską Rezydencja diabła z 1896 roku (org. Le Manoir Du Diable), w świecie filmu na stałe zagościły krwiopijcze postacie. Rok później opublikowana została powieść Brama Stokera, która utrwaliła się w wyobraźniach angielskich czytelników, tworząc klasyczny wizerunek wampira. Był to ubrany w wiktoriańskie szaty Dracula (Janion, 2002) - fikcyjny portret nieśmiertelnego Księcia Ciemności i władcy położonej pośród dzikich Karpat Transylwanii - którym według historycznych podań miał być okrutny XVI-wieczny palownik Vlad Tepes. W latach 20. XX wieku wdowa po Bramie Stokerze, Florence, nie wyraziła zgody na ekranizacje powieści jej męża. Niemiecki reżyser Friedrich Wilhelm Murnau postanowił jednak wykorzystać linię fabularną Draculi, zmieniając tylko imiona postaci. Na miejsce głównego bohatera zamiast szarmanckiego uwodziciela, wprowadził zaczerpniętego ze słowiańskiego folkloru Nosferatu - trupiobladego wąpierza o długich, zwierzęcych paznokciach, nienaturalnie dużych uszach, szpiczastym nosie oraz charakterystycznych wyostrzonych kłach na miejscu przednich jedynek, służących do wysysania krwi z ofiar.
\end{abstract}

Ogrody Nauk i Sztuk nR 2021 (11) 
Nosferatu - symfonia grozy, bodajże najpełniejsze dzieło. F.W. Murnau, z tytułową rolą autentycznego i sugestywnego Maxa Schrecka wpisało się w ekspresjonistyczne kino grozy, ukazując jednocześnie inny wampiryczny wymiar. Charakterystyczna wizja Nosferatu musiała jednak na kilka dekad ustąpić popularnym interpretacjom brytyjskiego reżysera Toda Browninga, który w 1927 stworzył interesujący i nowatorski Londyn po pótnocy, a następnie zaprezentował światu najpopularniejszy wizerunek wampira, będący jednocześnie pierwszą pełnoprawną adaptacją prozy Brama Stokera - w klasycznym filmie Dracula z 1931 roku. Motywy nakręcone przez Browninga powtarzały się w kolejnych wersjach Draculi: poczynając od tej wyprodukowanej przez słynne Hammer's Studio z Christopherem Lee w roli głównej, a kończąc na zjawiskowym Bram Stoker's Dracula Francisa Forda Coppoli (Ermida, 2016).

Pomiędzy kolejnymi odsłonami Księcia Ciemności przemierzającego „,oceany czasu" (Bram Stoker's Dracula, 1992, reż. Francis Ford Coppola) w poszukiwaniu utraconej przed wiekami ukochanej, w 1979 r. pojawia się formalny remake Symfonii grozy, czyli Nosferatu wampir w reżyserii monachijskiego twórcy Wernera Herzoga. Film został nakręcony w tzw. pełnym nowofalowym okresie kina niemieckiego. Charakterystyczną cechą tego nurtu było odwoływanie się do korzeni rodzimej kinematografii sprzed rządów Adolfa Hitlera, przede wszystkim do złotych czasów niemieckiego ekspresjonizmu. Równocześnie priorytetem filmowców doby Herzoga było stworzenie czegoś nowego. Herzog odwoływał się od pamięci o przeszłości. Krytycy oraz teoretycy kina przypisywali mu raczej cechy kina neoromantycznego, biorąc pod uwagę wszystkie cliché ${ }^{1}$ wykorzystywane przez reżysera (Sarbniewska, 2014). Dzięki oryginalnej narracji Wernera Herzoga Nosferatu wampir stał się nie tylko remakiem, lecz także osobną interpretacją klasycznej wampirycznej historii z niespotykanymi jak na ten typ dzieła filmowego alegoriami.

\section{ŚMIERĆ I DZIEWCZYNA}

W momencie, gdy Herzog decydował się nakręcić Nosferatu, wygasła licencja powieści Brama Stokera (Newby, 2019). Reżyser mógł zatem wykorzystać imiona bohaterów. Postać tytułowa nazywana jest w filmie hrabią Draculą. Pojawiają się Jonathan oraz Lucy, która jest główną żeńską postacią (w literackim pierwowzorze żoną Jonathana oraz ukochaną Draculi jest Wilhelmina Murray, zwana Miną).

Nosferatu nie pojawia się jedynie w tytule dzieła. Jego opisy ilustrują tajemniczą ludową księgę o strzygach i upiorach czytaną przez bohaterów w ramach instruktażu walki ze złem. Po swoim pierwowzorze Nosferatu Herzoga odziedziczył enigmatyczną i upiorną twarz. Został natomiast obdarzony temperamentem Klausa Kinskiego. Postacie portretowane przez Kinskiego w dziełach Herzoga nazywane są często „bohaterami Herzogowskimi" (Sarbniewska, 2014, s. 51). Wampir w ujęciu charyzmatycznego aktora jest szaleńcem oraz „niewolnikiem swojej pasji” (Sarbniewska, 2014, s. 51), odczuwającym pragnienie $\mathrm{w}$ dosłownym i przenośnym znaczeniu tego słowa oraz dążącym do osiągnięcia zamierzonych celów za wszelką cenę. Za akty pychy, podporządkowujący sobie ludzką wolę bohater Kinskiego, zostaje surowo ukarany. Jednocześnie pozostaje postacią pełną dumy - bestią zamkniętą $\mathrm{w}$ mrokach zamku,

1 Cliché - w znaczeniu filmowym „cliché" oznacza powtarzający się motyw. 
świadomą swojego pochodzenia oraz fatum; z drugiej strony zaś buntownikiem posiadającym cechy ludzkie, który nade wszystko pragnie zaznać miłości.

Końcowy los wampira w filmie Herzoga jest dwuznaczny. Hrabia Dracula naiwnie wierząc w oddanie i poczucie miłości został oszukany i przechytrzony. Słynny motyw z pianiem kura zapowiadający przyjście poranka wraz ze śmiertelnym dla wampira światłem słonecznym, wydaje się okrutniejszy niż w filmie Murnau, ponieważ unicestwia bohatera, który po raz pierwszy w przeciagu niezliczonych wieków samotności mógł poczuć się szczęśliwy.

Symbol miłości, który w filmie figuruje jako najczystsze uczucie, jest motorem działań Lucy. W filmie główna postać kobieca o twarzy Isabelle Adjani została przedstawiona jako osoba o niezmąconej grzechem duszy. Werner Herzog ukazał w finałowej scenie poświęcenia Lucy ważną symbolikę. Wykorzystał postać kobiety jako symbol przetrwania. W kontekście tej alegorii Lucy (Kobieta) była w stanie wydobyć z siebie tyle mocy oraz woli, by dzięki swojemu poświęceniu uratować miasteczko Wismar i ukochanego (Ludzkość). Herzog w swoich dziełach rzadko portretował kobiety. W przypadku Nosferatu oddaje kobiecie prawdziwy hołd. Lucy obdarzona została szlachetnością i odwaga, posiada kobiecy spryt, jednocześnie charakteryzują ją cechy matczyne, które widać przede wszystkim w scenach czułości. Emocję tą okazuje choremu Jonathanowi. Isabelle Adjani portretując Lucy, grała pod hipnozą (był to celowy zabieg będący nawiązaniem do symboliki ekspresjonizmu (Sarbniewska, 2014)), co zaowocowało dodatkowo tajemniczością jej postaci. Lucy przechodzi największą przemianę spośród bohaterów. Jej wizyjność i paranoje z początku filmu zamieniają się w siłę przetrwania. Tej przemianie towarzyszy jeszcze jedna scena, przedstawiająca dodatkowo typowe dla kina wampirycznego symbole związane z odkrywaniem własnej seksualności. Widać w niej Lucy siedzącą przed lustrem i rozczesującą włosy. Jej wyostrzone spojrzenie na własne odbicie nie oddaje już towarzyszących jej dotychczas zmartwień. Jednocześnie $\mathrm{w}$ tym samym momencie pojawia się cień hrabiego Draculi. Warto podkreślić, że scena ta pod względem filmowym, na podstawie oświetlenia i kreatywnego wykorzystania lustra jako przedmiotu grającego, została fantastycznie zainscenizowana. Podobnie jak ujęcie wieńczące losy Lucy oraz Księcia Ciemności, w którym kobieta zachęca wampira do dalszego spożycia jej krwi. Ukazanie cielesności w tej scenie sugeruje poczucie sensualności, odkrywania seksualności oraz możliwe erotyczne złudzenie, które doprowadza do przykrego końca. Postacie kreowane przez Adjani i Kinskiego pod pozorem archetypu odsłaniają złożone typy ludzkie - symbolicznie pozaświadome, odzwierciedlające najgłębszą prawdę o człowieku oraz jego naturze. Przy tym zabiegu wykorzystującym finezję kina ekspresjonistycznego, Herzog sięga jednocześnie po współczesne wzorce (Sarbniewska, 2014).

Nadanie Lucy i Draculi cech Herzogowskich prowadzi ich do egzystencjalnego błędnego koła. Oznacza to, że doświadczają cierpienia i samotności. Polski teoretyk filmowy Sobotka uważał, że „wszyscy bohaterowie Herzoga cierpią” (Sobotka, 1996, s. 167-186) a samotność często staje się gestem ich wyboru, będąc równocześnie wynikiem odrzucenia przez hermetyczne środowisko. Przypadek alienacji jest adekwatny do wampira - uosobienia zła. W przypadku Lucy społeczność Wismaru odrzuciła jej obserwacje i mobilizację do działania, choć gdyby reakcja była inna, rozwój sytuacji mógłby doprowadzić do pozytywnego rozwiązania i uratowania małżeństwa Harkerów. Ponownie - me- 
tafizyczne odczuwanie lęku pochodzącego od samotności oraz egzystencjalne cierpienie jednostki pozostawionej $\mathrm{w}$ niemocy $\mathrm{w}$ wielomilionowym świecie istnień ludzkich - prowadzi do tragicznego końca. Ten przejaw konstatacji, dzięki której Herzog koresponduje z filozofią Heideggera i Schopenhauera, Sobotka wyjaśnia jako celowe wprowadzenie bohaterów w przełomowych momentach ich życia. Zabieg ten zapowiada kres lub klęskę postaci, uosabiając fatalizm jej wyborów (Sarbniewska, 2014).

\section{NicośĆ CZŁOWIEKA WOBEC POTĘGI NATURY}

Sznyt artystyczny Wernera Herzoga kumuluje się w przypadku zamiłowania reżysera do pejzażystach ujęć odzwierciedlających w pełnym majestacie potęgę przyrody. Twórca kreuje tym samym hołd dziewiczym wyobrażeniom o planecie niezamieszkałej przez człowieka, równocześnie daje upust swojej plastycznej wrażliwości. Herzog jest przede wszystkim dokumentalista, następnie zaś wizjonerem (Sarbniewska, 2014). W treści autorskiej klasyfikację tę najlepiej obrazuje Aguirre: Gniew Boży - również z Klausem Kinskim w roli tytułowej (Sarbniewska, 2014). Odnajdziemy ją także w przypadku Nosferatu. Filmowa licencja na poetyczną inscenizację przychodzi mimowolnie i oddaje z płynnością pędzla wybitnego malarza filozofię środka, którą ma do zaoferowania Herzog.

Potęgę natury w Nosferatu oddaje sekwencja, w której Jonathan decyduje się na samotną podróż do zamku hrabiego Draculi. Młody prawnik przypomina w niej antycznego pasterza rodem z mitów greckich, archetypicznego myśliciela uwięzionego między karpackimi wzniesieniami wzbudzającymi grozę i zapierającymi dech $\mathrm{w}$ piersiach cudami ziemskimi. Herzog wskazując na poszczególne szczyty górskie oraz trudy wędrówki, staje się dyrygentem emocji widza. Ponadto droga Jonathana, aż do finałowego dotarcia do zamczystych ruin Księcia Ciemności odbywa się w akompaniamencie uwertury do symfonii Das Rheingold Richarda Wagnera, co dodaje tylko majestatu jego wędrówce. W tej sekwencji Werner Herzog wyraźnie inspiruje się dziełami Caspara Davida Friedricha. Nie osiagnąłby tego gdyby nie kunszt operatorski Jörga Schmidta-Reitweina. Szczególnie bliskie malarstwu jest wyeksponowanie ludzkiej sylwetki jako nierozerwalnej łączności z pejzażem a jednocześnie wyizolowanie jej maleńkości w obliczu bezkresnej potęgi świata (Sarbniewska, 2014).

\section{FOLKLOR}

Werner Herzog zadbał o to, by Nosferatu wampir nie zostało pozbawione ludowego wymiaru, podobnie zresztą jak w przypadku jego poprzednich fabuł. Aguirre: Gniew Boży z pietyzmem oddawał kulturę Indian Ameryki Południowej oraz hiszpańskich kolonistów doby renesansu. Zagadka Kaspara Hausera jest opowieścią w detalach skupiającą się na XIX-wiecznej niemieckości. W swoim jedynym horrorze Herzog ponownie $\mathrm{z}$ zamiłowaniem dokumentalisty buduje filmowe przestrzenie $\mathrm{z}$ naciskiem w podkreślaniu epoki oraz pojawiającej się na ekranie narodowości.

Scena pobytu Jonathana w karczmie obfituje w dokonaną przez Herzoga interpretację folkloru. Karczma ta jest bowiem kolebką karpackich górali oraz Cyganów. Romowie są istotni dla opowieści o Księciu Ciemności. Pojawiali się w wielu filmowych ekranizacjach Draculi jako mroczni na wpół zezwierzęceni słudzy. Nie przez przypadek łączy się fabularnie Romów z najsłynniejszym wampirem świata - w XVI 
wieku naddunajscy Romowie zostali sprowadzeni do roli niewolników w czasach, kiedy okrutny Vlad Tepes władał jeszcze Mołdawią i Wołoszczyzną. Herzog ukazuje rumuńskich Romów z innej perspektywy, nie zapomina jednak o ich trudnym położeniu. Przewodniczący taboru w mistyczny sposób wprowadza Jonathana w opowieści o demonach i upiorach. Scenie tej towarzyszy baśniowość. Folklor cygański pojawia się ponownie na zamku hrabiego Draculi. Za dnia pośród ruin zjawia się tam fałszujący na skrzypcach romski chłopiec.

Postój Jonathana w karczmie to także moment symboliki słowiańskiej. Babka wręczająca Harkerowi Księgę Demonów mówi po polsku. Kwestia ta zadręcza przede wszystkim polskich widzów przez co spotkała się z kontrowersjami i zarzuceniem Herzogowi ignorancji. Polski akcent pojawia się dodatkowo w scenie z flisakami, przepływającymi przez Dunaj z czarnymi trumnami należącymi do Draculi. Werner Herzog nie pomylił się wprowadzając polski akcent do Nosferatu. Karpaty oraz rzeka Dunaj przez kilka wieków funkcjonowały jak szlak handlowy - w tym dla polskich górali, których Herzog umieścił w filmowej narracji.

Tubylczość u Herzoga i jej powtarzająca się symbolika (jak ludowe interpretacje śmierci) są zabiegiem ironicznym. Wprowadzają element czarnego humoru. Za znamienity przykład może uchodzić tu barokowy zegar ścienny z otwierającą się trupią czaszką i kostuchą wychylającą się zamiast klasycznej kukułki w momencie wybicia pełnej godziny. Istny czarny humor w konwencji danse macabre nawiązujący do przepełnionych groteską i makabreską ilustracji Rolanda Topora - nomem omen pojawiającego się w Nosferatu wampirze w roli owładniętego szaleństwem Renfielda.

\section{Anihilacja}

Ujęcie otwierające Nosferatu wampir przypieczętowało główne przesłanie filmu. Wpisało się płynnie w estetykę horroru oraz wizji Herzoga, którym towarzyszy enigmatyczna muzyka krautrockowego zespołu Popol Vuh. W otwarciu filmu kamera najeżdża powoli na zesztywniałe i wysuszone sylwetki zastygłych $w$ cierpieniu ofiar. Ich wykruszone otwarte usta jednoznacznie wskazują na to, że ludzie Ci umierali w męczarniach. Ujęcie to sugeruje potencjalnemu widzowi, że mogłyby być to ofiary wampira. W rzeczywistości pozafilmowej są to mumie z Guanajuato w Meksyku. Współcześnie są częścią stałej wystawy jednego z najbardziej przerażających muzeów na świecie. Na przełomie XIX i XX w. do jaskini Guanajuato trafiały trupy osób zmarłych w wyniku epidemii cholery. Gdy choroba ustąpiła, jaskinia została przekształcona w celę skazańców dla przestępców oraz osób nieprzychylnych władzy. Byli tam grzebani żywcem pośród naturalnie zmumifikowanych ciał, wyschniętych na skutek wysokiej temperatury i braku wilgoci.

Ta makabryczna scena została własnoręcznie udokumentowana przez Wernera Herzoga podczas jego podróży do Meksyku. W kontekście filmowym wprowadza nas w to co w Nosferatu wampir nie zostało powiedziane dosłownie, dlatego uzupełnieniem dla tej pełnej mroku sceny, jest wmontowany lot nietoperza. Ten element zapowiada nam treść podstawową - historię Nosferatu opowiedzianą na nowo po przeszło pięćdziesięciu latach.

Gdy Jonathan lub Lucy odczytują słowa Księgi Demonów oraz w trakcie pobytu Jonathana na zamku Draculi, opisy i zachowania Księcia Ciemności nabierają zupeł-

Ogrody Nauk i Sztuk nR 2021 (11) 
nie innego niż przedtem wymiaru. Tytułowy wampir nie łaknie jedynie krwi. Wąpierz grany przekonywująco przez Klausa Kinskiego niesie za sobą śmierć w większej skali. Jest władcą szczurów, panem czarnej śmierci - dżumy. Wraz z hebanowymi trumnami Draculi do Wismaru przybywa także pomór.

W oryginalnym Nosferatu pojawia się wątek o morowej zarazie, ale nie został on przedstawiony na taką skalę jak w swoim godnym następcy. Estetyka śmierci toczy się przez cały film Herzoga. Można ją zauważyć w kadrze, w którym Lucy siedzi niewinnie na ławce pośród grobów na plaży. Śmierć jest znamienna w sekwencji masowego pochówku, gdy wymierać zaczynają mieszkańcy Wismaru. Przemarsz trumien i wprowadzenie barw: czerni oraz granatu uzupełniają lęk przed śmiercią i strachem przed nieznanym. Oba te czynniki zdefiniowały istnienie horroru w kulturze. W Wismarze wymierają wszyscy: ludzie oraz zwierzęta. Ocaleni popadaja stopniowo w skrajny obłęd. Ma to związek z obecnością Draculi, czyli uosobienia zła totalnego. Scena, w której Lucy Harker przechodzi przez rynek Wismaru, napotykając wcześniej szczury jest sugestywnym zainscenizowaniem wizji zagłady ludzkości. Na ziemi leżą zwierzęce szczątki, wszędzie panoszą się szczury, ostali ludzie są wyjałowieni. Nieopisany smutek i tragedia ludzkości - apokaliptyczna ciemność, która jest alegoryczna do trybu życia wampira, w którym świt miałby już nigdy nie nadejść.

Poświęcenie się Lucy dla ocalenia Jonathana i resztek mieszkańców Wismaru mogłoby stanowić pozornie szczęśliwe zakończenie. W Symfonii grozy mimo śmierci żony Harkera (w 1922 r. byli to Hutter oraz Ellen) Wismar oraz prawnik zostali uratowani. Zakończenie u Murnau pozostawia poczucie nadziei. Herzog burzy potencjalne szczęśliwe zakończenie. Najpierw doprowadza do obłędu profesora van Helsinga, który w szaleństwie dobija Draculę drewnianym kołkiem. Prawdziwe zdumienie następuje jednak potem. Okazuje się bowiem, że mimo poświęcenia Lucy i wyeliminowania Draculi, Jonathan nie ozdrowiał. Nie umarł, mimo to nie obudził się w ludzkim ciele. Nie pomógł mu magiczny okrag usypany ze świętej hostii przez jego troskliwą żonę. Scena finałowa przebudzenia Jonathana jest równocześnie najstraszniejszą sceną w całym filmie. Według Herzoga na miejsce poległego Nosferatu (alegorii zła) szybko może pojawić się kolejne. Niezrozumiałe są słowa Harkera, który do końca uległ procesowi zwąpierzenia: „Przyprowadź mi konia” (Nosferatu wampir, 1979, reż. Werner Herzog). W następnym ujęciu widać męską sylwetkę galopującą na koniu pośród pustki. Można by powtórzyć słowa Cyganki: „Śmierć podróżuje szybko” (Nosferatu wampir, 1979, reż. Werner Herzog). Nosferatu wampir nie posiada budującego na duchu zakończenia. Herzog odkrywa swoją twórczość ponownie jako pesymistyczną (Sarbniewska, 2014).

\section{EPILOG}

Nosferatu wampir nie jest jedynie remakiem ekspresjonistycznego arcydzieła. Werner Herzog poszedł o krok dalej rozwijając swoją reżyserką filozofię, przekraczając kolejne filmowe granice i redefiniując postać wampira w kinematografii. Nosferatu wampir spotkał się z ciepłym przyjęciem krytyków oraz widzów. Okazał się sukcesem komercyjnym oraz co najważniejsze artystycznym. Klaus Kinski powrócił w roli wampira w nieformalnej kontynuacji pod tytułem Nosferatu w Wenecji. 
Horror według Wernera Herzoga jest polem pełnym do najmożliwszych interpretacji. Pod względem namnożenia symboliki i treści nadaje się na ciąg dalszych rozważań. Stanowi także wielowymiarową inspirację, stąd w miejscu końcowej puenty warto dostrzec zależność między Wernerem Herzogiem a innymi artystami. O recepcji i zasięgu Herzogowskiego Nosferatu świadczyć można w duchu neoromantyczna i poniemiecka fala inspiracji. Pod wielkim wpływem Nosferatu wampir długo pozostawała brytyjska piosenkarka Kate Bush. W utworze Hello Earth wykorzystała gregoriański chór, który w filmie niemieckiego reżysera pojawił się w scenie apokaliptycznej: „,Tiefer, tiefer/Irgendwo in der Tiefe/Gibt es ein Licht”. Potwierdza to dziedzictwo nie tylko filmu, ale i wampiryzmu w ogóle. Bo czyż inspiracja ta nie jest $\mathrm{w}$ duchu wampiryczną Narzeczona z Koryntu zaczerpniętą wprost z Goethego?

\section{Bibliografia:}

[1] I. (2016). Dracula and the Gothic in Literature, Pop Culture and the Arts. Boston: Brill Rodopi.

[2] Herzog, W. (reżyser). (1979). Nosferatu wampir [film]. Werner Herzog Filmproduktion, Gaumont, Zweites Deutsches Fernsehen

[3] Janion M. (2002). Wampir. Biografia symboliczna. Gdańsk: Wydawnictwo słowo/obraz terytoria.

[4] Newby R. (2019). The Quiet Horror of ,Nosferatu the Vampyre' at 40. Pobrane z: https://www.hollywoodreporter. com/heat-vision/nosferatu-at-40-quiet-horror-werner-herzogs-remake-1247118.

[5] Sarbiewska J. (2014). Ontologia i estetyka filmowych obrazów Wernera Herzoga. Gdańsk: Wydawnictwo słowo/obraz terytoria.

[6] Sobotka K. (1996). Krzyk człowieka. Twórczość filmowa Wernera Herzoga. W: K. Sobotka (red.) Mistrzowie kina europejskiego (s. 167-186), Łódź: STO Films 